UDC 330.3

JEL Classification: 032

DOI: $10.15587 / 2706-5448.2021 .246402$ Article type «Reports on Research Projects»

\title{
Iegor Kartuzov
}

\section{ANALYSIS OF STATE OF THE ART «THREATS» TO UKRAINIAN STARTUPS}

The object of this research is a quick recap to assess barriers on startups evolution in Ukraine after acquiring an independence 30 years ago and those developed of today. The paper aims to analyze an impact of political, historical and other factors affecting startups evolution and to understand how it decelerates an efficient functioning of technology transfer process nowadays. If one wants to establish a successful and fast-growing business, then you may need to create your own startup. The experience and practice show that it is a rather complicated process, which follows a few factors and conditions that determine its success and/or failure at the end. Being based on previously proposed efforts devoted to succinct analysis of historical, political and other premises jeopardizing transfer in Ukraine, this one is to scrutinize startups as an effective tool for such a transfer. The result of this endeavor makes a solid background for further debates in terms of political science, legal regulations and export control associated with startups and technology transfer. They highlight that startups' and DUs' status quo implies that a global economy undergoes a number of changes related to demographic trends, technological advances, accelerated innovation and globalization. This study employs qualitative methodology and being under an umbrella of descriptive research design to accord on historical, technical, political, and other implications for startups origin as the effective mechanism for technology transfer and state's security. This descriptive research portrays a rather accurate profile of present situation around Ukrainian startups. This design offers a profile of described relevant aspects of the problem from author's individual perspective.

Keywords: startups evolution, start-ups environment, high-tech technologies, technology transfer, dual use technologies.

\section{Introduction}

Being based on previously proposed efforts [1-3] devoted to evaluation and succinct analysis of influence of historical, political, legal, mental and other premises affecting transfer of high-tech DU technologies in Ukraine, this one is to scrutinize startups as an effective tool for such a transfer. The result of this endeavor makes a solid background for further debates in terms of political science and legal regulations associated with startups and technology transfer. They highlight that startups' and DUs' status quo implies that a global economy undergoes a number of changes related to demographic trends, technological advances, accelerated innovation and globalization. All this has led to the fact that today there is a significant need to increase a level of entrepreneurship in Ukraine, which also plays a critical role in improving a steady growth of economy and national security. Startups super contribute to the improvement of state's technological advantage, which significantly increases the level of nation's well-being and leads GDP to an increase. The obstacle that entrepreneurs face is bureaucratic barriers to doing business. For greater effect, it is necessary to reduce those to the maximum. Successful business incubation used in developed countries has to rally state's support that facilitates a creation of new businesses and realization of potential growth.

Giving a birth to «knowledge-based business» brought to the emergence of a new type of active entrepreneur who applies advanced technologies and innovations and employs economic tools to commercialize those. If to analyze changes that have taken place in Ukraine over the past 30 years of independence, then one may conclude that if recently famous entrepreneurs were the owners of oil, metallurgical, railway and automotive industries, then in 1991-2021 famous businessmen mainly make money on data retention, information exchange, communications, gadgets, computer games and services. If one wants to establish a successful and fast-growing business, then you may need to create your own startup, which means a company or temporary organization created to find a repetitive and scalable business model [4]. A startup is a project with 
rather fast growth (about 5-7 \% per week) [5] and it offers a new product/service in conditions of high uncertainty [6]. Startup is a relatively new phenomenon in the Ukrainian economy. Its essence, specifics of functioning and management, the Ukrainian entrepreneurs community studies and borrowed from an experience of foreign businessmen who began to operate with this category in the first half of $\mathrm{XX}$ century. Thus, the startup is a process of entering the market by newly created enterprise with an innovative project, usually in the short term and minimum investment [7]. Or the startup is a newly created company (sometimes not even a legal entity) that is at a stage of development and builds its business either on the basis of new innovative ideas or newly invented technologies.

\section{Startup tags:}

- bearers of innovative ideas (startupers) are not always future leaders of a real enterprise;

- startupers usually look for an investor to implement an innovation;

- investing in a startup is always a significant risk, so often it requires for cooperation of startup team with venture institutions and business angels;

- a business model that transforms an idea in reality must have a tendency to scale - is a required condition for a liquidity of startup as a product on the world market and one of the first interests of a potential startup buyer; - startup classic objective - is to sale reliable business model;

- usually a cross-functional team works on a startup in conditions of uncertainty.

The above said does not pretend to be an exhaustive and complete list, yet allows to unambiguously interpret features and ignores popular and at the same time abstract characteristics, like: «quick investments return», «an idea that did not exist before», «recently created company» [7], «creative environment», «new innovative business», etc.

Ukrainian startup system was analyzed in [7-9]. However, in general, papers devoted to this topic [10-12] are fragmentary and do not provide a complete view, nor systematic and bear a comprehensive data especially when it comes to technology transfer. Analyzing a state of the art of startup movement in Ukraine, one may conclude that it is found in its infancy stage, characterized by moderate level of competition and, unfortunately, insufficient support from the state, national funds and business angels. If during the analyzed period under the first five presidents, the state totally ignored a solution of these issues, and national business made capital investments mainly in projects-schemes based on strong corruption foundations but activities of international funds (for example, CRDF Global [13]) with respect to startup issues were reduced to purely educational activities, then in mid-2019, the present government approved a «Strategy» how to development an innovation sphere up to 2030 [14]. It is a significant achievement for Ukraine, because throughout a history of independence, government officials and businessmen have constantly emphasized the expediency of forming an innovation-oriented economy yet came to nowhere. However, unfortunately, this document prepared (on behalf of the president) by old school officials who have not yet been replaced in the management staff is almost no different from their peers, because neither answers have been provided on funding mechanisms, nor responsible for implementing the strategy. The main goal of the Strategy is to build a holistic national innovation ecosystem to transform creative ideas into innovative products and bring them both to domestic and a world market. For modern Ukraine, this could be considered as a real achievement, cuz throughout the independence, constantly debating a need to develop an innovationoriented economy, the government could not adopt even a single document. It is if think positively, of course. If in essence, then this document is no different from other similar national strategies and projects - neither specific financing mechanisms, nor those responsible for its implementation, not to mention its conceptuality and proposed directions for solving existing problems, among which there was no place for industry! Of course, the Ministry of Education and Science is not engaged in industry, and the Department of Industrial Policy [15] of the Ministry of Economic Development and Trade is only concerned with «individual» innovations, therefore finally «we have what we have». The main thing is that as of today, the apparatus of performers of a new «European» type has not yet been formed to effectively resolve the problems associated with startups' establishment and methodology. «A level of government functionaries at all social levels is so low professionally, morally, intellectually, that not only the policy of elite contributed to a complete loss of control over the country, but also a shortage of personnel. I do not see any prospects yet. .... A small random person came to power. When a random person comes to power, this is very bad for the country and if this random person gains absolute power, it is a tragedy for the country» the quote from academician Yuri Ryzhov [16]. Even better quotation which celebrates its 89 anniversary belongs to Hares Jensen (1904-1971) political adviser to the chairman of the Social Democratic Labor Party of Sweden. He said: «When scientists, engineers, doctors and other intellectuals leave the country. A color of the nation the intelligentsia - is leaving, then businessmen rule in such a country, and the plebeians and swindlers from the street - politicians and market speculators, athletes and artists become parliament members» (from his speech at the Reichstag Committee on Migration and Demographic Policy, 1932). This could be definitely applied to almost all post-Soviet states including Ukraine and almost any temporary interval of their existence till present and joins to, proves and shows that namely the mental factor has an imperceptible, and often a decisive role in implementation of any reforms and state's policy. Thus, the approved Strategy once again demonstrated a lack of good interagency coordination and cooperation in state strategic planning. So, a main goal of the Strategy is to develop an integral national innovation ecosystem to turn creative ideas into innovative products/services and bring those to the Ukrainian market. Actually, only an implementation of ideas in real life makes 'em innovations. The existence of an idea in someone's mind, even the most unique, does not mean it is innovative. The idea must be sold, applied, disseminated, and only after becomes an innovation. Natural questions come: how to do it, how to overcome a notorious «valley of death», where most innovators fail? It takes a long time - sometimes decades - to create innovations from a scratch and from fundamental R\&D to bring an innovative product to the world market. This does not mean that fundamental science can be neglected, vice versa, its support is a solid 
basement of national security and a long-term investment in future sustainable development. The fastest way to produce innovations could be startups based on already existing developments of R\&D institutes and universities. Today, startups occupy its own soundable niche in global economy. In almost every country, centers and incubators are created on the basis of business, research institutions and universities, which actively promote their innovative ideas or products on the market. According to Startup Ranking [17], Ukraine ranks $43^{\text {rd }}$ (250 startups), ahead of Estonia, Lithuania, Latvia, Slovenia, and Slovakia. The first place in the ranking is occupied by the USA (46951 startups), the second - India (6633), the third - the United Kingdom (4996), the top ten is closed by Brazil (1079 startups) [18]. The number of Ukrainian startups grows every year, but, according to experts, on average, only $3-5 \%$ of all submitted projects are worth attention, and the result provides only $1-2 \%$. The main problem of startups in Ukraine is not only a shortage of talented staff, but also a lack of financial support for development of innovative goods and services. Only a small number of projects arrive at a stage of negotiations with investors, most - are rejected at the beginning. Often project managers do not even know how to start and present a startup professionally and strategically correctly. The main reason for this is ignorance of all legal procedures, imperfection or lack of legal framework, non-compliance with certain requirements for distribution of funds received from investors. As a result, the project does not develop or ceases to exist at all [19]. As of 2021, the market of Ukrainian startups is in a state of active development. Per StartupBlink [20] - Commercial Research Center for Startup Ecosystems of the World - Kyiv (412 operating startups) ranks $48^{\text {th }}$ meanwhile in 2017 , Kyiv ranked $64^{\text {th }}$ out of more than thousand cities around the world. Such a rapid rise of 29 positions in one year indicates a significant shift in development of Ukrainian startups, which are growing quite rapidly and have many users. Ukraine as a whole ranks $34^{\text {th }}$ all over the world.

For Ukraine, with its scientific and innovative potential, 250 startups is a meager amount. Even their successful further development will not resolve a problem of low level of national innovative development, startups are in demand much more. Often, information about an establish- ment of new Ukrainian startups appears, its ratings are formed due to draw an attention to those and provide inspiring examples for inheritance. Rating of Ukrainian startups of 2021 [21] according to Forbes (Table 1).

Thus, the above list of not all Ukrainian startups proves their success both in the Ukrainian market and abroad. Companies such as Ajax Systems, Monobank, Rocket, Grammarly, Uklon have already become well-known and recognizable brands, which products and services are used by Ukrainian and foreign consumers. The Ministry of Digital Transformation of Ukraine presented to the investment market in the USA the idea of launching a so called «Fund of Funds» [22] in Ukraine. The purpose of this is that the state provides from 10 to $20 \%$ of budgeting for the Fund of Funds, the rest is to be provided by other microfinance organizations (MFOs), and then the Fund of Funds invests in other funds, which, in turn, would contribute to companies and projects predominantly focused on hi-tech or IT sectors. On the part of the United States, participation/ partnership of venture and institutional funds with the Ukrainian Fund of Funds is expected. The total amount of financial support starts at USD 7 million. The Fund of Funds is in the process of implementation, its launch is scheduled for 2022 .

The purpose of this effort is to analyze an impact of political, historical and other factors affecting startups evolution and understand how it affects an efficient and proper functioning and optimization of technology transfer process nowadays.

Thus, the object of this research is a quick recap to assess barriers on startups evolution in Ukraine after acquiring independence 30 years ago and those developed nowadays.

\section{Methods of research}

Mechanisms for actual viz. commercial transfer of production technologies of advanced materials of dual-use through Ukrainian startup mechanism virtually does not exist due to a strong political, security and legal reasons. Despite the above startups and a transfer of sensitive technologies and conditions associated with it have continued to ignite a huge interest in the last decade worldwide. The process of technology transfer through a startup mechanism as a whole is not simple and far from being perfect as of yet, especially when it comes to dual use (DU) technologies.

Rating of Ukrainian startups of 2021

\begin{tabular}{|c|c|c|c|c|}
\hline Rank & Information & Industry & Evaluation & Investment \\
\hline 1 & Gitlab & Development & 6 billion USD & 234 million USD \\
\hline 2 & Grammarly & Webservices & 13 billion USD & 11 million USD \\
\hline 3 & Ajax Systems & 5mart devices & from 500 million USD & 107 million USD \\
\hline 4 & People.ai & CRM & $420-500$ million USD & 55 million USD \\
\hline 5 & Restream & Streaming & $220-250$ million USD & 0 \\
\hline 6 & MacPaw & Apps & $100-300$ million USD & 50 million USD \\
\hline 7 & Jiji & Electronic commerce & $150-200$ million USD & 51.3 million USD \\
\hline 8 & Preply & Dnline-studying & $130-200$ million USD & 0 \\
\hline 9 & Depositphotos & Photobank & $90-200$ million USD & 0 \\
\hline 10 & Jooble & Job search & USD 110 million USD & C5D \\
\hline 11 & CEX.ID & Cryptocurrencies & $70-120$ million USD & \\
\hline
\end{tabular}

Note: the table is based on data [21] 
Thus, this effort is to analyze and scrutinize factors being staying in between technology supplier/recipient as well as future prospects and real steps forward. The study employs qualitative methodology and is under the umbrella of a descriptive research design to agree on historical, technical, political, and mental implications for a startups origin as the mechanism for technology transfer and state's security. Political, and legal analysis are conducted in relation to these technologies, actions and questions popped up nowadays associated. This descriptive research portrays a rather accurate profile of current situation happened around Ukrainian startups. This design offers a profile of described relevant aspects of the problem of interest from author's individual perspective.

\section{Research results and discussion}

As one may observe, a breakthrough was made in areas where a size of start-up capital was rather sufficient and it took a relatively short period of time before success was manifested, however, the Foundation's support extends only to four areas of application:

- development of modern information and communication technologies and robotics;

- development of new technologies for energy transportation, introduction of energy efficient technologies, development of alternative energy sources;

- development of new technologies for materials produc-

tion, creation of industry of nanomaterials and nanotechnologies;

- introduction of new technologies and equipment for high-quality medical care, pharmaceuticals.

All this gives a hope for full effective progress forward. The Fund is of 3.8 million USD. In case of passing through selection process, winners of competition at the first stage of state incentives receive services worth up to approximately 19 thousand USD. Services include business model development, laboratory testing, patent preparation, patent analysis, etc. At the second stage, based on the results of assessment of startup team, prospects, patent purity and terms of implementation of startup idea, a decision is made to provide support in the amount of up to 76 thousand USD. Consequently, the maximum amount of support per project would make around 98 thousands USD.

Secondly, the Ukrainian Fund of Startups (UFS) [23], which began its operations on July 11, 2019. The UFS budget is 14.9 million USD, the amount of grant for one project makes from 25 to 75 thousand USD for the duration of its implementation up to 24 months. It turns out that with such a budget, from 240 to 720 startups can be financed. At first glance, not bad for two years. (For comparison, in 2017 the size of investments in Israeli startups exceeded 5.5 billion USD, in $2018-6$ billion USD (according to the Start-Up Nation Central report)). The total volume of transactions for the purchase of Israeli startups in 2017 exceeded 24 billion USD. In 2019, the total volume of exits of high-tech Israeli startups in 138 transactions amounted to 21.7 billion USD [24]. Yet the volumes of investments and conditions of support in Ukraine and Israel are incomparable. The State of Israel assumes the risks of startups during the first two years: it invests $85 \%$ of investments (up to 500,000 USD) in one startup project, another $15 \%$ is contributed by a startup team and business incubator. In Ukraine, the distribution of these percentages is exactly vice versa. It can be assumed that the selected startups do not need significant amounts of funding, but in case of the Invention Support Fund, this is not the case at all, because the four selected priorities of state funding for projects require large investments ... and therefore, the funding problem remains the same. To reduce the risks of public investment in start-up projects, it is worth again looking at how this practice is established in successful innovative countries. For example, in Israel, startup ideas are very carefully selected: out of 200 ideas, 40 are selected, of these 40 , only 8-12 startups are selected for placement in business incubators. Eight startups usually become successful, that is, $20 \%$ (out of 40 selected), while their share in the world on average is about $10 \%$. Under such a scheme, the state fully returns the invested funds and even receives more, for example, from the WAZE (navigator) startup [24], the state received six times more funds than invested.

At the heart of Ukrainian startups very bright and interesting ideas could be found, which implementation requires large investments. In overwhelming majority of cases, it makes no sense for Ukrainian startup to set up a company in Ukraine, just as it makes no sense to work for a local market when there is a large and solvent foreign audience. It also makes no sense in order to attract Ukrainian investors - there are not so many of them in the country, and if there are some then they prefer to invest mainly in something more tangible, familiar and understandable (for example, buying a sand pit, which immediately gives $300 \%$ of the profit). Many startups specifically try to attract foreign investors not only for the sake of financial injections, but also for the sake of their business connections, market knowledge, experience and reputation [25].

Now let's consider a sensational CFC (controlled foreign companies) law. On May 22, 2020, Volodymyr Zelensky, the president of Ukraine, signed the law No. 466-IX [26] «On amendments to the Tax Code of Ukraine regarding the improvement of tax administration, elimination of technical and logical discrepancies in tax legislation» (bill No. 1210), largely implementing the norms of the BEPS (Base Erosion and Profit Shifting) plan in the Tax Code of Ukraine ( $(\mathrm{TCU})$ ). The law introduces the rules of controlled foreign companies («CFCs»), which significantly change rules of the game for Ukrainian individuals and legal entities that own structures abroad. The CFC rules came into force on January 1, 2021. The law was adopted and the mechanism was trigged. More and more businessmen wonders to what extent it concerns them and put the questions: «what is this abbreviation», «what consequences, thou it has», «is it necessary to do something or not». One may endlessly debate a «correctness» of its adoption, scrutinize and criticize its inconsistencies and imperfections, but the law has already become a part of legal reality of Ukraine. It is interesting to see if legislator's goal matches the consequences. The law was adopted and actively promoted under a halo of combating against money laundering and tax evasion due to return «home» capital from «seditious» offshore companies.

Nevertheless, key factors that guide startupers when deciding a perspective to register a company abroad are not tax evasion only, but:

1. Investors focus. The goal of startup when attracting investment is not only to advertise itself from the best 
side, but also to convince an investor that investing is safe and secure, and procedural moments are manageable. That is why they prefer familiar system of English law, a respectable and «understandable» jurisdiction.

2. Comprehensible contracts. When concluding a deal, one may take into account that English contract law differs significantly from the Ukrainian one, even in basic terms. Also, the fact that practice of settling such relations in accordance with English law is much more common in the world, and, therefore, texts of agreements are more perfect and account for all nuances.

3. Courts reputation. When entering into legal relationship (even if a startup is cool and an investor promised to invest millions), one should take off your rose-colored glasses and think in advance what to do if something goes wrong. In this case, the initial choice of jurisdiction and dispute resolution mechanisms is extremely important and can sometimes play a cruel joke. Thus, one may to recall the assessment of rule of law in the rating, imagine how often Ukrainian courts face these cases, and how a court decision in relation to foreign company will be implemented.

4. Geographical reasons, i. e. targeting a specific market when developing an innovative product. The Ukrainian market is small, confined and less solvent than for example, the European one. One may try to develop locally, focus on local consumer, but sooner or later new markets shall be defined and innovative ideas shall be presented to the world community. Immediately a need to accept international payments and compliance to requirements of international banks may pop up.

5. Banking system compliance. Thus, choosing a bank that is reliable and convenient for investor is an extremely important factor when concluding a deal. Not every bank is ready to open an account to make an investment for a startup. Especially when it comes to big amounts, and startupers are from Ukraine. Contemporaneously, time factor for startupers plays a quite crucial role. An investor does not want to bother with a deal for years, flying back and forth, and to provide a helluva amount of documents with further translation of those into Ukrainian, notarization and validation of those in numerous institutions.

Considering all these factors, one may to conclude that ownership or control over a foreign company for a startup or already established business is conscious necessity for successful development and almost inevitable. Thus, the business environment in Ukraine is so changeable and risky in itself that any business a priori becomes risky and, in many cases, untransparent and sometimes even illicit, thou. In addition to broad debates of some aspects of essence and features, the effective startup activities in Ukraine are nowadays hampered by:

1. Lack of clear mechanism for public management of startup activities. In order to fully employ startups potential as a catalyst for development of state's economy and means of diffusion of innovations, the state must develop a mechanism for clear and licit management of startups.

2. Failure to address corruption of public authorities involved to attracting investments into state's economy.

3. A significant level of monopolization of many business areas, as a rule, by representatives of oligarchic-political circles who consider startups as a direct potential threat to their monopolized and often low-competitive business.

4. Low quality of startup education system. There are some associations of startupers, often training courses, which are reduced to retelling stories of success yet not business owners efforts to provide layman with the right answers to questions.

5. Significant blurring and non-public nature of transactions at startup market [8].

The above is not a final list but allows to outline the main obstacles for startups in Ukraine.

Thus, a «fiery» «Strategy» - «development of a holistic national innovation ecosystem to turn creative ideas into innovative products/services and bring 'em to the world market», eventually lost this approach. Nevertheless, one may also look at the experience of the National Academy of Science. During the last 20-30 years, a priority was given to the issues of innovative development of economy and its industries. Not by chance that at NASU institutes pilot production facilities were created to take all risks of going through $\mathrm{R} \& \mathrm{D}$ to implementation stage to exclude the «death alley». Today, not only the material basis of this experience is mostly destroyed, but the experience itself is forgotten. Or maybe it's worth saving at least something at the end? There was also an excellent experience gained by former 20 complex target programs carried out by the institutes of NASU. Indeed, quite recently, scientists were actively involved in ensuring the innovative development of Ukraine to be considered by the National Security and Defense Council and such a catastrophic state, as now, was avoided. At that time, the scientists of the «Resource» [27] program dealt with these issues and the results obtained have could become a solid background for creation of hundreds of startups and thousands of small enterprises aimed at solving the most actual and pressing problems (monitoring of technical condition and extension of safe operation of industrial equipment, nuclear and thermal energy facilities, building and transport infrastructures, bridges, aerospace products, accounting for changes in materials properties during longterm employment of those in aggressive environment). These results can also provide and contribute to development of an effective transfer of technologies through startups, which are in demand in Europe and the United States, China and other investment-active countries.

\section{Conclusions}

The analysis showed that the world experience gained in start-ups environment as an effective tool for transfer of high-tech technologies in Ukraine is well known, and through the efforts of educational activities of international foundations is at a fairly good level of practical recommendations, it has been brought to the attention of research community - bearers of these technologies. Nevertheless, the political factor being super-dominant till 2019, almost blocked this path for transfer. Since 2019, a negative categorization of this factor has a bit decreased, but other inhibiting factors (i. e. covid pandemic) joined in.

The period from 2019 till present, witnesses that the main battleground in promoting startups is the mental factor. On the one hand, this is the latent sabotage of old-school officials operating (quite highly professionally) with corruption schemes (for personal gain and enrichment) for oligarchs who need a quick and guaranteed elevation of profit (while has not yet been taken away), and all these are far from being startups. On the other hand, it is an activation of the initiatives of technology carriers in order 
to attract investments to scientific research in connection with the drastic lack of basic budgetary state funding.

For Ukraine with its powerful and internationally recognized, scientific and innovative potential, start-ups as the tool for implementing innovations in high-tech technologies (including dual-use) may resolve the most pressing problems of economic development, and through 'em, a formation of powerful and prosperous European state and this is the economic factor that has not yet said its decisive word.

Thus the result of this research makes a solid background for further debates in terms of political science, legal regulations and export control associated with startups and technology transfer.

\section{Acknowledgements}

This effort and the research behind would not have been possible without the exceptional support and initial impetus of my supervisor, prof. Dr. Quentin Michel. His enthusiasm, knowledge and exacting attention to every detail have been an inspiration and kept my work on track from my very first encounter with political science and legislation referred particularly to export control and transfer of dual use technologies in the EU and Ukraine.

\section{References}

1. Kartuzov, I. (2021). An impact of political, historical and mental premises on dual-use technologies transfer in Ukraine. Technological and Scientific Innovation: Networks, Geography and Policy. Lisbon.

2. Kartuzov, I. (2020). Dual-use material science technologies transfer in ukraine: premises and present catch-22. ScienceRise, 5, 95-102. doi: http://doi.org/10.21303/2313-8416.2020.001477

3. Kartuzov, E. V., Quentin, M. (2019). Barriers in technology transfer of advanced DU materials in Ukraine. Bulletin of the Ukrainian Materials Science Society named after Academician I. M. Frantsevich, 12. Available at: http://www.materials. kiev.ua/article/2955?sect id=4

4. Blank, S., Dorf, B. (2013). Startup. Founder's Handbook. Moscow: Alpina, 132.

5. Graham, P. (2012). What has changed in the world of startups Startup investing trends. Available at: http://www.paulgraham. com/growth.html

6. Pic, E. (2012). Business from scratch. Lean Startup method for quick testing of ideas and selection of business model. Moscow: Alpina Publisher, 234.

7. Mrykhina, O. B., Stoyanovsky, A. R., Mirkunova, T. I. (2015) Startup companies perspectives in the contextof competitive development of ukrainianhigh technologies market. Actual problems of economy, 9, 215-225.

8. Ivashova, N. V. (2013). Start-up proekty-instrument realizatsii innovatsii. Ekonomichni problemy staloho rozoytku, 4, 115-116
9. Lalu, F. (2017). Companies of the future. Kharkiv: KSD, 544.

10. Gavrish, O. A., Boyarinova, K. O., Kopyshynska, K. O. (2019). Development of startup projects. Kyiv: KPI named after Igor Sikorsky, 116.

11. Gavrish, O. A., Dergachova, V. V., Kravchenko, M. O. (2019). Management of startup projects. Kyiv: KPI named after Igor Sikorsky, 337.

12. Polishchuk, V. V. (2018). Startup projects and their evaluation. Uzhhorod: UzhNU, 74.

13. About Us. CRDF Global. Available at: https://www.crdfglobal. org/who-we-are/about-us

14. Strategy for the development of innovation for the period up to 2030 (2019). Order of the Cabinet of Ministers of Ukraine No. 526-p. 10.08.2019. Available at: https://zakon.rada.gov.ua/ laws/show/526-2019-\%D1\%80\#n12

15. MERT sozdal departament po voprosam prompolitiki $i$ vvel dolzhnost zamministra. Interfaks-Ukraina. Available at: https://interfax.com.ua/news/economic/367571.html

16. Yuri Alekseevich Ryzhov. Available at: https://en.wikipedia.org/ wiki/Yuri_Alekseevich_Ryzhov

17. Startup Ranking. Available at: https://www.startupranking.com/

18. Evtushenko, V., Kudinova, M. (2019). Trends of development of startups movement in Ukraine. Black Sea Economic Studies, 48. doi: https://doi.org/10.32843/bses.48-37

19. Ivanchenko, N. O., Podskrebko, O. S., Sidletska, A. O. (2020) The Main Problems and Prospects for the Development of the Startup Market in Ukraine. Business Inform, 4 (507), 303-311. doi: http://doi.org/10.32983/2222-4459-2020-4-303-311

20. Global Map of Startup Ecosystems - StartupBlink. Haifa: Global Map of Startup Ecosystems (2020). StartupBlink. Available at: https://www.startupblink.com/startups

21. TOP-30 luchshikh startapov Ukrainy po versii Forbes. Available at: https://inventure.com.ua/analytics/articles/top-30-luchshihstartapov-ukrainy-po-versii-forbes

22. Mintsifry rabotaet nad sozdaniem v Ukraine Fonda fondov dlya IT-proektov (2021). Interfaks-Ukraina. Available at: https:// interfax.com.ua/news/investments/765871.html

23. Grant USF. Available at: https://usf.com.ua/en/grant-usf/

24. Yushkevich, N. (2020). The startup ecosystem of Israel. Startup Jedi. Available at: https://startupjedi.vc/ru/content/startap-ekosistema-izrailya

25. Skorokhod, V. V., Firstov, S. A., Kartuzov, V. V. (Eds.) (2005) V. I. Trefilov. Zhizn i deyatelnost. Vospominaniya. Izbrannye trudy. Kyiv: Academperiodika. Available at: http://www.nbuv.gov.ua/ node/924

26. Pro vnesennia zmin do Podatkovoho kodeksu Ukrainy shchodo vdoskonalennia administruvannia podatkiv, usunennia tekhnichnykh ta lohichnykh neuzghodzhenostei u podatkovomu zakonodavstoi (2020). Zakon Ukrainy No. 466-IX. Available at: https://zakon. rada.gov.ua/laws/show/466-20\#Text

27. Derzhavna naukovo-tekhnichna prohrama «Resurs» (2004). Postanova Kabinetu Ministriv Ukrainy No. 1331. 08.10.2004. Available at: https://www.kmu.gov.ua/npas/9679013

Iegor Kartuzov, Department of Political Science, European Studies Unit, University of Liege, Agora, Belgium, ORCID: https://orcid.org/ 0000-0001-7493-674X,e-mail: iegor.kartuzov@student.uliege.be 